\title{
ADVERSITY QUOTIENT IN LEARNING MATHEMATICS (COMPARATIVE CASE STUDY IN CLASS VIII MTS)
}

\author{
Zubaidah Amir MZ \\ ${ }^{a}$ Mathematics Education Departement, Universitas Islam Negeri Sultan Syarif Kasim, Riau, Indonesia \\ Corresponding e-mail: zubaidah_mz@yahoo.com,
}

abstract: The aim of this study was to analyze the validity and reliability scale Adversity Quotient (AQ) / power struggle and analyze AQ mathematics students in learning. This research is a comparative study on students at MTs Al-Munawawarah PP Pekanbaru, eighth grade students consisting of 25 girls and 21 boys. The study shows that the AQ scale category contains and empirically valid. AQ the analysis concluded that there was no difference in the power struggle student (AQ) math students between the male students to female students. Likewise, in terms of all indicators AQ both groups of students. AQ consists of five indicators, namely control, origin, ownership, reach, and Endurance which respectively mean to the two different groups. Through variance test, the data indicators and data capabilities AQ AQ Mathematics students both homogeneous group. Male students were higher in aspects of endurance and range. while female students are better able to control themselves in menyelesaian mathematical problem. This study contributes to the literature study to identify factors that affect students' mathematical power struggle and efforts should be made to enhance the fighting power (AQ) is one of them through the application of metacognitive learning in mathematics

Keywords: Adversity Quotient (AQ), gender, metakognitive.

\section{INTRODUCTION}

Mathematics learning aims for students to have an attitude appreciate the usefulness of mathematics in studying the problem, and a tenacious attitude and confidence in solving problems. That is important to be studied further in the psychological aspects of learning mathematics. One of the psychological aspects of learning is a power struggle in the face of obstacles (Adversity Quotient) (Zubaidah, 2014).

AQ means someone fighting spirit in the face of obstacles / barriers. Stolz (in Sudarman 2012) states that the Adversity Quotient is the persistence in overcoming obstacles in climbing the peak of success desired. so in mathematics learning meaningful as persistence learn some vital lessons mathematics student overcome difficulties to achieve success.

Adversity Quotient (AQ) has four key dimensions which form the basis of the measuring instrument adversity quotient in students. Dimensions constituent expressed Stoltz (2006), namely: 1) Control (Control), 2) Origin and
Ownership (ownership), 3) Reach (Reach), and 4) Endurance (Endurance). Dimensional controls with regard to a person's response to adversity, either slow or spotan. Ownership dimension is the extent to which a person feels he or she can correct the situation. Dimensions range is the extent to which the acquired difficulties to penetrate his life. Dimensions resilience reflects how a person perceives difficulties and therefore able to survive through it. Overall score determines the capacity of a person in the face of adversity.

According to Stoltz (2006) there are three types of $A Q$, namely: type quitter (low AQ), type camper (AQ medium), and the type of climber (high AQ). Type quitter is a student trying to get away from the problems. Characteristics of children quitter type, for example: his business was minimal, so look at the difficulty he would have chosen to retreat, and did not dare to face the problems. Quitter students are those who think that math is complicated, nyelimet, confuse, and headache alone. Their motivation is lacking, so that when it finds sedidkit difficulty in solving math problems they give up and quit without accompanied by the slightest effort. 
Type camper is a student who did not want to risk too much and feel satisfied with the condition or circumstance that has been achieved today. In mathematics learning camper is not as hard as possible, they tried to moderation. They argued that it does not need to pass an important high value, do not need to champion an important grade. Type climber is a student who has a goal or target. To achieve that goal, he was able to pursue with tenacious and persistent. Not only that, he also had the courage and discipline. Students climber is they enjoy learning mathematics. The tasks that the teacher completed properly and on time. If they find difficult math problems done, then they tried as much as possible until they can get it done.

Learning mathematics is considered as a difficult subject and intimidating for students. Tatang Herman (2011) revealed that most students at the elementary level has a positive impression of the mathematics, but decreases when entering high school. Therefore, it is necessary to study further how psychological students learn in mathematics, in this case including guts / adversity quotient. Equally important factor is the factor of sex students (gender). Gender differences necessarily lead to differences in physiology and affects the psychological differences in learning. Students so that men and women would have a lot of differences in learning mathematics. Results writing by Wigfield and Meece (1988: 210-212) that assess differences in age and gender, renspon of boys and girls through MAQ concluded that negative attitudes toward female students math stronger than male students at ages 6, 7, 9, and 11 years. Based on the above exposure, researchers examined more about AQ mathematics students to develop and test the scale AQ AQ mathematics students at MTs level in this case study in MTs Pondok Pesantren Al-Munawarah Pekanbaru.

Problem formulation in this research is: How can the validity of AQ Scale developed ?, Is there a difference between AQ boys with a female student in mathematics?, How AQ mathematics students of MTs Al-Munawwarah Peknabaru?

\section{METHODOLOGY}

This research is a comparative case study on students of MTs PP Al-Munawwarah Pekanbaru. The population is all that and a sample student eighth grade daughter Aisha numbered 25 people and class VIII Abu Bakar amounted to 21 people. Research procedure: starting with developing the
AQ scale based on the study of literature and test validity to the Expert. Expert in this case is an expert in the field of Educational Psychology (lecturer fak. Psychology UIN Suska Riau) which consists of 3 people. Based on expert advice, AQ scale and further revised in ujicobakan empirically in other schools comparable with the population, which in MTsPP Darel Hikmah Pekanbaru Once tested, then analyzed to see the validity and reliability of the AQ scale. Scales have been used to valid and reliable research sample.

Data were analyzed with descriptive statistics and inferential statistics. Descriptive statistics yitu by finding the average value (mean), the percentage $(\%)$, and provide labels for each indicator category (low, medium, high) and AQ each student (very low, low, medium, high, very high). Inferential statistics with kompaaratif test (t-test) by first assuming normal distribution of data matching and homogeneous. The raw data previously transformed into interval data using the MSI program (Exell).

\section{FINDING AND DISCUSSION}

\subsection{Development Adversity Quotient Scale}

IQ scale previously formulated in 5 indicators of the number of items totaling 40 . The statement is based on expert advice, then the AQ scale to 39 items with less of the item is deleted because it was considered less relevant and 7 revised editorial statement item / items. The scale was developed with four option choices: Often Once (SS), often (S), Rare (J), once rare (JS). Based on empirical testing, there are seven items that are not valid and can not be used, so that the final item numbered 32 with the details in Table 1 below:

Table 1. Distribution of Item AQ Indicator

\begin{tabular}{|l|l|}
\hline Indikator & Item Number \\
\hline Control & $1,2,3,4,5,6,7,8$ \\
\hline Origin & $9,10,11,12,13,14$ \\
\hline Ownership & $15,16,17,18,19,20,21$ \\
\hline Reach & $22,23,24,25,26,27$ \\
\hline Endurance & $28,29,30,31,32$ \\
\hline
\end{tabular}

Each indicator, consisting of a few grains of positive statements (favorable) and negative (unfavorebel). To test reliabelitas, obtained $\mathrm{r}=0.8$. it can be concluded that the scale used has a high relaiabilltas (Anwar, 2002), and means (variations) that appear 
on the score scale is capable of reflecting $80 \%$ of the variation that occurs in pure scores of the sample group. in this case can also be said that $20 \%$ of the difference in scores that appear due to errors or variations of the measurement error.

\subsection{Ability Adversity Quotient (AQ) mathematics Students}

Class VIII Aisyiyah a daughter's class consisted of 25 students. While Abu Bakr VIII class is a class of men consisting of 21 students. Based on data analysis of data categories guts (Adversity Quotient / AQ) math students in table 2 below:

Table 2. Data category of student Math Adversity Quotient

\begin{tabular}{|l|r|r|r|r|r|}
\hline Category & \multicolumn{3}{|c|}{ Quitter } & $\begin{array}{c}\text { Cha } \\
\text { mper }\end{array}$ & \multicolumn{2}{c|}{ Climber } \\
\cline { 2 - 6 } & $\begin{array}{l}\text { Very } \\
\text { low }\end{array}$ & \multicolumn{1}{|l|}{ low } & Moderate & high & $\begin{array}{c}\text { Very } \\
\text { high }\end{array}$ \\
\hline Male & 0 & 2 & 5 & 11 & 3 \\
\hline Female & 0 & 1 & 8 & 15 & 1 \\
\hline
\end{tabular}

From Table 2 above, it appears that there are 3 boys were categorized AQ is very high, and only one category of students who are very high. For high category more girls than boys, is 15 people. Similarly to moderate, eight daughters and five sons. None of the students the very low category.

For Champer category, there are three students with distribution of 2 sons and 1 daughter. While Champer category, there were 13 students with the distribution of 5 sons and 8 daughters. For climber category there are 30 students with the distribution of 14 sons and 16 daughters. thus descriptively not too much difference between boys and girls for each category AQ. Of the three categories of the AQ, most students are in the category of AQ climber, which is high and very high. For the percentage of each category can be seen from Table 3 below:

Table 3. Persentage AQ Category

\begin{tabular}{|l|c|l|l|l|l|}
\hline \multirow{2}{*}{ category } & \multicolumn{3}{|c|}{ Quitter \% } & $\begin{array}{l}\text { Champer } \\
\text { \% }\end{array}$ & \multicolumn{2}{c|}{ Climber \% } \\
\cline { 2 - 6 } & $\begin{array}{l}\text { Very } \\
\text { low }\end{array}$ & low & moderate & high & $\begin{array}{l}\text { Very } \\
\text { high }\end{array}$ \\
\hline Male & 0 & 9,52 & 23.81 & 52.38 & 14.29 \\
\hline Female & 0 & 4 & 32 & 60 & 4 \\
\hline
\end{tabular}

From Table 3 above, it appears that over $50 \%$ of both male and female students of high category, and less than $10 \%$ of both male and female students were low category.

Inferentially, through the test of difference (t-test) obtained $t$ count of 0.3 . For a significant level of $5 \%$ $\mathrm{t}$ critical $=2$. Because $\mathrm{T}$ count is smaller than the critical t, we can conclude there is no difference between willpower (AQ) math students between the male students to female students. The mean value of boys and students daughters respectively $(53,04)$ and (61.82). although the average of female students is higher than male students, but this is due to differences in the number of each sample.

Diversity fighting spirit (AQ) male students gained 159.39. whereas the data variance AQ student daughter 98.89. This indicates that the data AQ male students are more diverse when compared with female students, the student category AQ students more homogeneous when compared to male students. However, in the second test of variance derived class $F$ counted 0.6 is smaller than the calculated F 1.6, so it can be concluded that both classes of data for the dissemination of homogeneous data.

\subsection{Indicator Adversity Quotient (AQ)}

Fighting spirit (AQ) math students consists of five indicators with each indicator consists of several items / item statement. The following percentage data for each indicator in Table 4 below.

Tabel 4. Persentage of Recapitulationi AQ Indicator

\begin{tabular}{|l|c|c|}
\hline Indicator & Male (\%) & Female (\%) \\
\hline Control & $\begin{array}{c}62,03 \\
\text { (moderate) }\end{array}$ & $\begin{array}{c}45.7 \\
\text { (moderate) }\end{array}$ \\
\hline Origin & $\begin{array}{c}74,5 \\
\text { (moderate) }\end{array}$ & $\begin{array}{c}41,13 \\
\text { (moderate) }\end{array}$ \\
\hline Ownership & $\begin{array}{c}68.65 \\
\text { (moderate) }\end{array}$ & $\begin{array}{c}51,6(\text { moderate } \\
\text { ) }\end{array}$ \\
\hline Endurance & 82,52 (High) & $\begin{array}{c}52.9 \\
\text { (moderate) }\end{array}$ \\
\hline
\end{tabular}

Data from Table 4 above, both female students, four of the five indicators of AQ worth more than $50 \%$ and only one was less than $50 \%$. That is, all the indicators are categorized as moderate. While for male students all indicators more than 50\%. There 
are two indicators are categorized as high and others moderate.

Table 5. Mean of Recapytulation AQ Indicator

\begin{tabular}{|c|l|l|}
\hline Indikator & \multicolumn{1}{|c|}{ Male } & \multicolumn{1}{c|}{ Female } \\
\hline Control & $\begin{array}{l}57.26 \\
\text { (moderate) }\end{array}$ & 78.67 (moderate) \\
\hline Origin & $\begin{array}{l}67.65 \\
\text { (moderate) }\end{array}$ & $\begin{array}{l}51.25 \\
\text { (moderate) }\end{array}$ \\
\hline Ownership & $\begin{array}{l}66.76 \\
\text { (moderate) }\end{array}$ & 76 (moderate) \\
\hline Reach & 76.78 (High) & 69 (moderate) \\
\hline Endurance & 82.87 (High) & 72.8 (moderate) \\
\hline
\end{tabular}

From Table 5 above, for male students, indicator control is the lowest indicator among other indicators. As for the female students, which is the lowest indicator in indicators of origin (the origin). Opposite with male students, the female students aspect of control is the most high, moderatekan on male students, aspects of the range is the aspect most high compared to four other indicators. In other words, female students tend to feel that the issues / problems faced more from myself, but more self-control. This is in contrast with the male aspect of self control is lacking. In addition, male students were able to keep the range of problems they face, so it does not engage in other aspects of life. Likewise, addressing the issue of durability (not easily discouraged), it turns out the male students is high compared with female students.

Nevertheless, AQ For indicator that consists of 32 items the statement, through the test of difference $(\mathrm{t}$ test) data showed $t$ 1.78. For a significant level of $5 \% \mathrm{t}$ critical $=2$. Because $\mathrm{T}$ count is smaller than the critical $t$, we can conclude there is no difference between the indicators of the power struggle (AQ) math students between male students-with a female student. The mean value indicator of male students and female students respectively (70.56) and (77). whereas for the diversity of value of all items on the statement of the two groups, through the test of variance, obtained $F$ count of 0.6. It is smaller than the critical $\mathrm{F}$ is 1.69 . thus the diversity of indicator values in both groups inferentially there is no diversity. That is the diversity of the data item is the same / homogeneous. Each indicator averaging the data for groups of male and female students further described in the following table.

Tabel 6. Category Indikator Control

\begin{tabular}{|c|c|l|l|l|}
\hline Item & \multicolumn{2}{|c|}{ Female } & \multicolumn{2}{|c|}{ Male } \\
\hline 1 & 65 & Moderate & 62 & Moderate \\
\hline 2 & 71 & Moderate & 69 & Moderate \\
\hline 3 & 77 & High & 70 & Moderate \\
\hline 4 & 71 & High & 59 & Moderate \\
\hline 5 & 69 & Moderate & 68 & Moderate \\
\hline 6 & 76 & High & 67 & Moderate \\
\hline 7 & 75 & High & 70 & Moderate \\
\hline 8 & 75 & High & 73 & Moderate \\
\hline
\end{tabular}

Table 7. Categori Indicator Origin

\begin{tabular}{|r|r|l|r|l|}
\hline Item & \multicolumn{2}{|c|}{ Female } & \multicolumn{2}{|c|}{ Male } \\
\hline 1 & 57 & Moderate & 65 & Moderate \\
\hline 2 & 62 & Moderate & 64 & Moderate \\
\hline 3 & 67 & Moderate & 69 & Moderate \\
\hline 4 & 72 & Moderate & 78 & Moderate \\
\hline 5 & 73 & Moderate & 81 & High \\
\hline 6 & 80 & High & 86 & High \\
\hline
\end{tabular}

Table 8. Categori Indicator Ownership

\begin{tabular}{|c|c|l|c|l|}
\hline Item & \multicolumn{2}{|c|}{ Female } & \multicolumn{2}{|c|}{ Male } \\
\hline 1 & 85 & High & 70 & Moderate \\
\hline 2 & 54 & Moderate & 63 & Moderate \\
\hline 3 & 76 & Moderate & 84 & High \\
\hline 4 & 71 & Moderate & 78 & Moderate \\
\hline 5 & 82 & High & 79 & Moderate \\
\hline 6 & 66 & Moderate & 79 & Moderate \\
\hline 7 & 63 & Moderate & 75 & Moderate \\
\hline
\end{tabular}

Table 9. Kategori Indikator Reach

\begin{tabular}{|c|r|l|r|l|}
\hline \multicolumn{1}{|l|}{ Item } & \multicolumn{3}{|c|}{ Female } & \multicolumn{2}{|c|}{ Male } \\
\hline 1 & 77 & Moderate & 88 & High \\
\hline 2 & 73 & Moderate & 86 & High \\
\hline 3 & 64 & Moderate & 83 & High \\
\hline 4 & 65 & Moderate & 88 & High \\
\hline 5 & 73 & Moderate & 89 & High \\
\hline 6 & 80 & High & 92 & High \\
\hline
\end{tabular}

Tabel 10. Category Indicator Endurance

\begin{tabular}{|c|r|l|r|l|}
\hline \multicolumn{1}{|l|}{ Item } & \multicolumn{2}{|c|}{ Female } & \multicolumn{2}{|c|}{ Male } \\
\hline 1 & 77 & Moderate & 89 & High \\
\hline 2 & 73 & Moderate & 85 & High \\
\hline 3 & 53 & Moderate & 64 & Moderate \\
\hline 4 & 59 & Moderate & 88 & High \\
\hline 5 & 77 & Moderate & 97 & High \\
\hline
\end{tabular}

From Table 6, for the control indicator, visible all statement items for male students categorized as moderate, but for female students, there are 5 of 8 were categorized as high. It is claimed that more female students who have control response in the face of difficulty learning mathematics.

Based on Table 9 and Table 10, high category dominated by male students. In other words, more 
male students of high ability to limit the reach of the difficulties it faces and more resilient in the face of problems. Resilience in overcoming the problem can be said is not easily discouraged.

When you see the AQ indicators, a student who has the ability to control the response in studying, more resilient and not easily discouraged, it is associated with aspects of process control in the student's own thinking. If students are able to think about the process of thinking, the students will understand the nature of what is the difficulty in learning mathematics and what he has or what he had planned to overcome these difficulties. In other words, students need to get used to control the thinking process called metacognition. It is appropriate Scoenfeld opinion (in Gartmann et.al., $(2012 ; 9)$ that metacognition is a habit in controlling the process of cognitive behavior, "Control or selfmonitoring of one's thought processes". Metacognition is defined as awareness of "thinking about thinking" that means bepikir about thinking. Swanson defines metacognition as "... the knowledge and control one has over's thingking and learning activities. ..." (Kramarski et. al., 2002; 225).

\section{CONCLUSIONS}

Based on the analysis, obtained some conclusions; IQ scale developed is valid or unfit for use. Nonetheless scale developed yet provide balance to the positive and negative statements and the number of grains of each indicator. This can be a concern for other researchers. However it contains, scale developed is valid.

In addition, it can be concluded that there is no significant difference between male students AQ with female students. however descriptively it can be seen that the mean AQ female students is high when compared with male students. This can be caused due to the number of different samples, this can be a concern for other researchers. In addition, the comparative test conducted on only one kind of school (boarding school), to further assess the comparative can be done with various schools (MTS MTS PP-PP) and (MTSsPP-regular MTs).

AQ of 5 indicators, it can be concluded that male students are more likely to be able to restrict the range of mathematical problems encountered when compared with female students. In addition, male students had more endurance (not easily discouraged) when compared to female students. In contrast, female students are better able to control themselves response to the difficulties in learning mathematics than male students. Therefore we need a learning strategy in an effort to improve student $\mathrm{AQ}$, in this case one of them is learning metacognitive.

\section{ACKNOWLEDGEMENTS}

This research involves many parties, therefore, authors on this opportunity to thank the school kepad PP MTs Al-Munawwarah which permit carrying out the research, told the Psychology Expert gives advice; Mother Vivik Sofiah, M.Psi, Beautiful Praise Ratnani, M.Psi, and Reni Susanti, M.Psi.

\section{REFERENCES}

Allan Judith dan L. Meece Wigfield Math Anxiety in Elementary and Secondary School Students. Journal of Educational Psychology, 1988, Vol. 80, No. 2, 210216. Copyright 1988 by the American Psychological Association, Inc. 0022-0663/88/\$00.7

Azwar, Syaifudin. (2002). Penyusunan Skala Psikologi. Yogyakarta; Pustaka Belajar

Kramarski, Bracha et al. (2002). The Effects of Metacognitive Instruction on Solving Mathematical Authentic Tasks. Educational Studies in Mathematics. Vol. 49, No.2

Shirley Gartmann and Melissa Freiberg. (2012). Metacognition and mathematical Problem Solving: helping student to ask The Right Questions. Jurnal TME Online, vol 6, number 1 . by the Mathematics Education Student Association at The University of Georgia. All rights reserved. http://math.coe.uga.edu/tme/issues/v06n1/3gartmann.p df diakses Oktober 2013.

Stoltz, Paul G. (2004). Adversity quotient mengubah hambatan menjadi peluang. Alih bahasa T. Hermaya. Jakarta: PT Gramedia Widiasarana Indonesia.

Sudarman Sudarman, (2012). Adversity Quotient Kajian Kemungkinan Pengintegrasiannya dalam Pembelajaran Matematika. Jurnal Aksioma, Volume 01 Nomor 01 Maret 2012

Tatang Herman, (2011). Revitalisasi Pendidikan Matematika untuk Mencerdaskan Kehidupan Bangsa. Pidato Pengukuhan Guru Besar dalam Bidang Pendidikan Matematika pada Fakultas 
Pendidikan Matematika dan Ilmu Pengetahuan Alam Universitas Pendidikan Indonesia, Kamis, 16 November 2011.

Zubaidah Amir MZ. 2014). Adversity Quotient; Kajian Kemungkinan Pengintegrasian dalam Pembelajaran Metakognitif Think-Aloud dalam Setting Kooperatif Think-Pair-Square. Proseding Seminar Nasional Pendidikan Matematika dengan tema "Implementasi Kurikulum 2013 dalam Pembelajaran Matematika". ISBN. 978-602-7648-05-0 Bandung: UNINUS 